\title{
Hambone's Call: Nathaniel Mackey and Editorial Poetics
}

\author{
"'Hambone, Hambone, where you been?" \\ "Around the world and I'm going again!"”
}

In an essay titled 'Editing Hambone' (2000), writer and editor Nathaniel Mackey looks back on the history of the literary journal he has edited and published since early in his career. Mackey recounts that the journal was founded in the early 1970s as the publishing outlet for the Committee on Black Performing Arts at Stanford University, where he was a graduate student. ${ }^{1}$ When the initial editor left Stanford before the first issue was completed, Mackey took over the editorship and published the inaugural issue in the spring of $1974 .^{2}$ He published that first issue under a new and noteworthy title, Hambone, the figure of a call-and-response rhyme, the name of an improvisational musical practice, and the title of an Archie Shepp jazz composition released on Fire Music in 1965. Despite assembling an exciting first issue that included a handful of writers who are well known today-Michael S. Harper, Gloria Watkins (bell hooks), Ishmael Reed, and Al Young — the Committee stopped publishing the journal following Mackey's own departure from Stanford shortly after the publication of Hambone 1. Mackey considered reviving the journal for several years before he returned to it in the early 1980s, this time as its sole editor and publisher. ${ }^{3}$ Hambone had called him back.

Since the publication of Hambone 2 in the fall of 1982, the journal has appeared regularly, with intervals of about one year in the 1980s and early 1990s that have since lengthened to two or three years. The widening frequency of publication has had a close correspondence with the development of Mackey's own writing career. While he had published a 
chapbook (Four for Trane, 1978) prior to resuming his editorship of Hambone, his first booklength works did not appear until the mid-1980s. Eroding Witness, his first book of poetry, was selected by Michael S. Harper for the National Poetry Series and published in 1985 by the University of Illinois Press. Bedouin Hornbook, volume one of Mackey's ongoing epistolary fiction about an avant-garde jazz ensemble — now in its fifth volume—was published in 1986 as part of the Callaloo Fiction Series. Mackey's distinct contribution to American letters has since become increasingly visible, signaled in recent years by his receipt of the National Book Award for Splay Anthem in 2006, a Guggenheim Fellowship in 2010, the Ruth Lilly Poetry Prize in 2014, and the Bollingen Prize in 2015. These last two, arguably the two most prestigious prizes in American poetry, were awarded for lifetime achievement, making some space in Mackey's diffuse and still-growing body of work for considering his particular accomplishments as the editor of Hambone, now in its twenty-first book-length volume.

Drawing out Mackey's editorial work with Hambone from under the more capacious umbrella of lifetime achievement shows how his editorship takes part in his poetics of 'discrepant engagement'. Mackey describes discrepant engagement as constituted by 'practices that, in the interest of opening presumably closed orders of identity and signification, accent, fissure, fracture, incongruity, the rickety, imperfect fit between word and world ${ }^{9}{ }^{4} \mathrm{By}$ emphasising the 'practices' that open up 'presumably closed orders of identity and signification', Mackey invites closer consideration of the editorial practices that lead to the singular Hambone. These too have sought to open closed orders of signification in American letters by drawing together a provocative assortment of writers and their varied experiments in language. Mackey has noted, for instance, that his journal became 'significantly different upon resuming publication' in $1982 .{ }^{5} \mathrm{~A}$ close look at the table of contents shows the difference. Whereas 
Hambone 1 features work of African American writers, composers, and artists almost exclusively, ${ }^{6}$ Hambone 2 and all subsequent issues publish African American writers alongside a variety of ethnic writers, most often Euro-American and Caribbean authors. Consider the contents of Hambone 2. The American poet Susan Howe's selection from Defenestration of Prague (1983) weaves together "sylvan imagery"7 from Edmund Spenser and reports of early colonial contact with American Indians to create a 'fugitive dialogue of masterwork' ${ }^{8}$ that reflects allusively on histories of colonialism. ${ }^{9}$ Howe's contribution corresponds with Edward Kamau Brathwaite's, the Barbadian co-founder of the Caribbean Artists Movement, whose contribution to Hambone 2 examines varieties of affiliation-filial, maternal, historical, (post)colonial, creative - at work in Barbadian culture and poetic creation. Mackey's own prose - an early letter from his ethereal epistolary fiction From a Broken Bottle Traces of Perfume Still Emanate - resonates with the dream-fiction of Caribbean couvade central to the excerpt from The Sleepers of Roraima: A Carib Trilogy (1970) contributed by Mackey's closest literary mentor, the British-Guyanese writer Wilson Harris. Elsewhere in the volume, surprising con- and disjunctions take shape between Sun Ra's Christian-inflected cosmic philosophy and the religious tracts of colonial Puritans such as Cotton Mather, assembled in a selection from Paul Metcalf's Golden Delicious (1985).

Metcalf himself responded to the variety of writers in the issue with delight. In a congratulatory letter to Mackey, Metcalf ponders 'How could anybody include [John] Taggart and [Ishmael] Read [sic] in the same magazine? Well, Nate Mackey could, that's how / who'. ${ }^{10}$ Metcalf's comment hints at the discrepant engagements taking place between the covers of Hambone, where John Taggart's spare and repetitive lines of poetry take their unsettled place beside Ishmael Reed's rhetorically bombastic interview addressing an ongoing feud with Amiri 
Baraka. Yet the opening lines of each contribution offer unexpected connections. Taggart's poem begins, 'Very slow from very far away child in slow motion / child not red angel child ignited'. ${ }^{11}$ Reed, by comparison, launches his attack with 'Mr. Baraka’s primitive European God-Devil system needs to conjure a satanic force, and so for many years he's been trying to paint me into a conservative corner'. ${ }^{12}$ A close reader such as Metcalf could be left to wonder whether Taggart's 'child not red angel child ignited', which the reader comes to realise is not a satanic image (red angel) but rather the atrocious image of a child aflame in American napalm, results from the 'primitive European God-Devil' system that Reed sees Baraka conjuring. Such an unlikely point of correspondence in writers who might not otherwise be read side by side—with Taggart most often associated with Objectivist poetry and Reed with African American and postmodern fiction—exhibits the kind of rickety fit made possible through Mackey's editorial practice of discrepant engagement.

As a printed manifestation of discrepant engagement, Hambone displays the imperfect fit not only between the word and the world, as Mackey states explicitly, but also between the word and the world of letters, by which I mean the nebulous constellation of practices, outlets, apparatuses, and discourses that constitute literary culture in the United States. In this, Mackey's editorial project joins a range of editorial interventions that have sought to reshape the contexts and aesthetic commitments of postwar American literary culture. In his essay on editing Hambone, Mackey acknowledges several of his literary forebears, including 'Coyote's Journal, Credences, Io, Isthmus, Montemora, New Wilderness Letter, and New World Journal' ${ }^{13}$ Although titles such as New World Journal and Isthmus remain obscure, even in the world of small-scale poetry publishing, the idiosyncratic effects these journals had on American literary culture were enough to encourage Mackey's later editorial efforts. Like each of these journals, 
Hambone takes shape as a 'particularist undertaking ... with a certain drive, which every magazine should have, toward ensemblist identity and definition'. ${ }^{14}$ Each editorial project, that is, maintains its own stylistic and operative idiosyncrasies while also welcoming its own ensemblist dis-organisation. Hambone is a materially bound printed object and also a conceptually bound 'literary journal' whose formal protocols remain largely intact. What it brings together, however, strains against Mackey's own organizing rubrics as well as those of the world of letters he seeks to test.

Imagining an editor overcome by his own creation is a suitably Frankensteinian tale of assembled form, with the monster articulating its own being more eloquently than its assembler ever could have, and this image opens on to my essay's arguments. Mackey's editorship of Hambone develops an editorial poetics whose discrepant engagements challenge claims that experimental forms and practices are doomed to be incorporated by popular culture, ${ }^{15}$ softened by secondary avant-gardes ${ }^{16}$ or recuperated by an economic logic that operates within critical discourses about avant-gardes. ${ }^{17}$ His editorial poetics instead offers a counterpoint to assertions about the "centripetal currents" ${ }^{18}$ of experimental practice by showing that editorship works by way of 'centrifugal or polycentric judgment and address'. ${ }^{19}$ While Mackey's editing results in the singular Hambone, Hambone's corpus is multiple; its assembled form articulates a disposition at odds with Mackey's particularist endeavour. Hambone thereby forms an opening for literary hospitality that confounds the 'closed orders' of categorical thinking that discrepant engagement protests against. Like the practice of discrepant engagement, Hambone calls 'attention to the problematics of rubric-making ... to make the act of categorization creak', a creaking often missed 'only because we agree not to hear it'. ${ }^{20}$ Hambone is a call and response to the literary 
field. It invites us to listen for the creaking that emerges from editorial poetics so that we might hear what tales the rasping Hambone has to tell. ${ }^{21}$

\section{Hambone's History}

The Hambone with whom most Americans would be familiar is the figure of the vernacular rhyme, which has had various iterations in popular song. In response to the question, 'Hambone, Hambone, where you been?', Hambone replies ‘Around the world, and I'm going again'. The origin of the rhyme remains irretrievable. Its structure and figure, however, derive from the traditions of African and African American music and the cultural legacies of slavery. In the opening chapter of African American Music, the editors write that 'by the third decade of the seventeenth century, accounts of New World music-making by African slaves, as observed by slaveholders, travelers, and missionaries began to surface. Sources such as diaries, journals, reports, and memoirs provided firsthand documentation of the activities of Blacks, noting the use of antiphony as a recurrent musical structure'. ${ }^{22}$ In a marginal gloss the authors define antiphony as 'a performance practice in which a singer or instrumentalist makes a musical statement which is answered by another soloist, instrumentalist, or group. The statement and answer sometimes overlap. Also called call-response; call-and-response'. ${ }^{23}$ Antiphony is thus among the earliest recorded Black ${ }^{24}$ musical forms in America and an important point of reference for Mackey, who concludes his essay on editing Hambone remarking that, 'as in the music the journal's name refers to, this is what one wants: that the call not go without response' ${ }^{25}$ Hambone's call to contemporary experimental writers works as a literary variation of longstanding antiphonal practices in Black music. 
Like so many African cultural traditions, antiphonal music adapted quickly to the conditions of enslavement in the New World and helped to form an oppositional and creative response to the world's most violent division of labour. Lawrence W. Levine writes on the topic of 'African American Music as Resistance' in the antebellum period, reporting that 'the overriding call-and-response pattern that Blacks brought with them from Africa ... placed individuals in continual dialogue with each other. The structure of their music presented slaves with an outlet for individual feelings even while it continually drew them back into the communal presence and permitted them the comfort of basking in the warmth of shared assumptions that permeated the slave songs' ${ }^{26}$ Individual expression in the service of communal solidarity — which calls to mind Mackey's characterisation of Hambone as a particularist undertaking with an ensemblist identity—paints a warm picture here. Yet Levine reminds his reader that the establishment of strong individuality and community through antiphony forms a protest against the condition of enslavement. 'In no other expressive medium', he writes, 'were the slaves permitted to speak so openly of the afflictions of bondage and their longings for freedom. In this sense, there was always an element of protest in the slaves' religious songs' ${ }^{27}$ The figural Hambone's flight into the world appears more secular than the religious songs to which Levine refers, but its protest is equally persistent. What better figure to protest enslavement, forced labour, and involuntary travel than one who flees unfettered into the world? Hambone is always summoned by an initial call, or more provocatively, the call itself is a response to Hambone's reappearance from elsewhere. Yet his response to that call—I have returned from a trip around the world - anticipates another departure: and I'm going again. The antiphonal balance between caller and respondent is thus maintained in the rhyme, even while the possibility of freedom and protest remain in the closing response. 
In addition to being the figure of an antiphonal rhyme, hambone is also a musical practice. Burnim and Maultsby define hambone as 'a form of rhythmic body percussion that involves slapping the hands against the thigh and hipbones'. ${ }^{28}$ Also known as 'pattin' juba', hambone's origins are as murky as those of the rhyme. In a documentary called The Human Hambone (2005), the historian Margaret Washington acknowledges that hambone almost certainly stems from African traditions, but she also gives a reason for its unique persistence in the United States. In the colony of Carolina in September of 1739, slaves initiated what became known as the Stono Rebellion. The largest slave rebellion of the eighteenth century in North America, the rebellion and its eventual suppression by a local militia claimed the lives of 'approximately 40 blacks and 20 whites' ${ }^{29}$ The legal consequences of the rebellion were severe. Washington reports: 'It created the Negro Act of 1740. They [the slaves in Carolina] lost the de facto right to learn to read and write and they lost the right to use their own African instruments' ${ }^{30}$ These remarks imply that hambone persists in North America as a creative response to dispossession. With the complete ban of drumming and literacy, enslaved Blacks turned to what we should understand as both traditional and improvisational forms of creative expression, hambone being one form among them.

Mackey has adapted hambone's history of dispossession and protest to the contexts and conditions of intellectual and artistic labour in the US today. If hambone arose as a creative and oppositional response to forcibly closed orders of identity and signification, then the journal asks how the repercussions of such creative protest might reverberate in the world of contemporary letters. In Bedouin Hornbook (1986), Mackey calls on this history of musical dispossession explained by Margaret Washington, but sets it out in the language of the fiction's theoretically adept characters. The narrator, N., writes letters to his correspondent, known only as 'Angel of 
Dust', to tell him about his experiences as a member of an experimental jazz ensemble. Nearly three years after N. begins writing to Angel of Dust, the instrumental band has begun to consider adding a drummer. Two of N.'s bandmates, Lambert and Penguin, hold different opinions about whether the band needs a drummer, and if it does, about how to select one. Lambert takes a strong position on including a drummer, suggesting that the band's current methods are rather makeshift. To this point Penguin makes an impassioned rebuttal, narrated after-the-fact by N.: ... he went on to say that the more crucial point he wished to make was that the approach Lambert had referred to as makeshift, disparaging it on historical grounds, was not without historical precedent, not without a certain sanction from the past. He reminded us that in this country, unlike places like Trinidad, Cuba and Brazil, the drums had been taken away during slavery ... This theft, however, he encouraged us to recall, had given rise to a tradition of oppositional, compensatory or, if we would, makeshift practices, a making do with whatever came to hand whose inaugural 'moment' was marked by more emphatic recourse to such things as footstomping, handclapping and the-body-used-as-drum in general ... He took this 'moment' to be the seed of such subsequent developments as the tendency to reinstate, as it were, the outlawed or abducted drum by taking a percussive approach to ostensibly non-percussive instruments. ${ }^{31}$ While Penguin does not refer to the Stono Rebellion in particular here, his plea demonstrates Mackey's familiarity with the history of musical dispossession for slaves in North America. The response to such dispossession took form in 'oppositional, compensatory', and 'makeshift' practices such as hambone: 'the-body-used-as-drum'. Mackey's Hambone records the creative repercussions of historical dispossession that Mackey himself outlines in Bedouin Hornbook. 
The makeshift — a word that hints at discrepancy, as that which makes shifts — merges with the oppositional in an operative sense: the assemblage of writers the journal publishes makes improvisation and rickety fits into a form of creative dissent.

\section{Hambone's Expeditions into Wholeness}

Mackey's decision to change the name of the Stanford-based journal to Hambone in 1974 was one of his first significant editorial interventions in a career now filled with them. ${ }^{32}$ The worldtraveling Hambone prefigures the journal's two primary emphases: on what Mackey has called 'centrifugal poetics', which he associates most closely with Black creative expression; ${ }^{33}$ and on the cross-cultural dynamic of American literature, whereby African American writing crosses paths with Afro-Caribbean, Euro-American, and other national and ethnic writing as it appears in Mackey’s milieu. Mackey has been resolute in publishing and promoting work by Caribbean writers in the pages of Hambone, for instance, and he has regularly included selections from Fred D’Aguiar, Kamau Brathwaite, Édouard Glissant, Wilson Harris, Mark McMorris, and M. NourbeSe Philip, among others. In addition to publishing these writers, Mackey also draws on their work to inform his own poetics. When Mackey describes his vision for Hambone as promoting 'cross-cultural work with an emphasis on the centrifugal' in his brief essay from 1995, he adopts the critical idiom of Édouard Glissant and Wilson Harris to conceive of Hambone as a cross-cultural collaboration that gives rise to a centrifugal poetics, perpetually in flight, but always touching down briefly. ${ }^{34}$ In this case, the figural Hambone touches down in the printed pages of a literary journal.

These pages develop an 'emphasis on the centrifugal' that Mackey adapts from the work of Wilson Harris, who outlines his understanding of centrifugal poetics with 'his notion of the 
partial image, the therapeutic work of a play of images around the acknowledgment of a partiality one strives to overcome' ${ }^{35}$ Mackey quotes a 1986 interview with Harris at length to draw out this idea:

Well, as I tend to see it at this point in time, there is a kind of wholeness, but one can't structure that wholeness. One knows it's there and one moves into it ceaselessly, but all the time one moves with partial images. Now the partial image has within it a degree of bias but it also represents a part of something else, so that there is a kind of ceaseless expedition into wholeness which has to do with the ways in which one consumes - metaphysically consumes - the bias in the partial image and releases that image as part of something else which one may not be immediately aware of in that context—one may not be immediately aware of how the partial image links up with another partial image until the centre of being in an imaginative work breaks or moves and the illusory centrality of the partial image is enriched in creative paradox. ${ }^{36}$

The process Harris describes here wavers between the centrifugal and the centripetal. We see this most clearly in the paradoxical directionality of his phrase 'ceaseless expedition into wholeness'. The prefix 'ex' should not be overlooked, for it marks a movement outward. Yet Harris says that the partial image prompts an expedition into wholeness, suggesting an irrevocable complementarity between a centrifugal expedition and centripetal consolidation. Harris's point is that the partial image finds unexpected supplements as it moves 'outward' and thereby moves into new provisional forms of wholeness that one can be aware of but 'can't structure'. As the final lines of the passage indicate, the provisional wholeness breaks down only to enrich the 
partial image 'in creative paradox'. With its illusory centrality lost, the partial image launches outward from the compromised totality in its ongoing 'expedition into wholeness'.

Harris's notion of a ceaseless expedition into wholeness aptly characterises the vernacular Hambone's journey into the world. Consider the etymology of 'expedition'. It derives from the verb expedite, which comes from a Latin verb meaning "“to free (a person's) feet from fetters" ... hence, to free from difficulties, to help forward, to get (a work) out of hand, to dispatch, send off, etc.' ${ }^{37}$ The etymology is provocative when considering Hambone as a figure of perhaps African and certainly African American provenance. Hambone's freedom to travel can be read as a response to having one's feet fettered — impeded — as a result of enslavement. In response to forced travel, an African American oral tradition makes Hambone into a figure of free expedition, traveling around the world at a whim. The 'world' Hambone travels around, moreover, stands in for the imagined wholeness to which Harris refers. Harris's vision of a centrifugal poetics compelled by the 'partial image' that seeks wholeness thus finds a related figure in Hambone, whose feet are freed for his journey into a wholeness he will never achieve but will continue to strive after. ${ }^{38}$

Mackey complements his philosophy of centrifugality and poetic itinerancy with crosscultural poetics, particularly as developed by the Martinican writer Édouard Glissant. ${ }^{39}$ Mackey quotes Glissant at length in his introduction to Discrepant Engagement, drawing primarily on Glissant's essay 'Cross-Cultural Poetics' (1973):

The issue . . . is the appearance of a new man, whom I would define, with reference to his 'realization' in literature, as a man who is able to live the relative after having suffered the absolute. When I say relative, I mean the Diverse, the obscure need to accept the other's difference; and when I say absolute I refer to 
the dramatic endeavor to impose a truth on the Other. I feel that the man from the Other America 'merges' with this new man, who lives the relative; and that the struggles of peoples who try to survive in the American continent bear witness to this new creation. ${ }^{40}$

Glissant's word choice here lays out the terrain in which Mackey also works. With the 'Other America' he refers to 'the Caribbean and South America' to oppose the tendency to identify 'American' as U.S. American. ${ }^{41}$ And by 'the Other' he refers to those who have been considered the Others of Western modernity, i.e. non-Western-European, enslaved, and colonised peoples. The two converge in Glissant's thought to offer up a 'new man' who 'is able to live the relative after having suffered the absolute'. This 'new man' again bears a striking resemblance to Hambone, who flees the fetters of enslavement, which must be understood as the most violent 'endeavor to impose a truth on the Other'.

Hambone, however, represents the failure of this endeavor: the Other cannot be subsumed under the absolute of Western modernity. Hambone instead works in opposition to the impulse to impose Otherness upon him. Like the new man and the partial image, Hambone tracks an outward-moving freedom by finding lines of flight within the totality that Western modernity supposed itself to be. As Glissant notes further on in his essay, "The collective "We" [an Other American "We"] becomes the site of the generative system, and the true subject. Our critique of the act and the idea of literary creation is not derived from a "reaction" to theories which are proposed to us, but from a burning need for modification' ${ }^{42}$ For Glissant and for Mackey, the generative system that emerges from the collective work of cross-cultural poetics puts the provisional apparatuses of modification — and the lines of flight — in motion. In forming 
a generative system that remains operative in practices such as Mackey's editorial poetics, Other American literature provokes a centrifugal impulse in the heart of Western literary modernity.

While Hambone becomes a figure of freedom in the above reading, Mackey's journal asks how we might make a record of his flight and thereby make Hambone's ongoing expedition into a centrifugal and generative force in American literature. Glissant proposes that a 'new man' finds his 'realization in literature'. The vernacular Hambone likewise finds one realisation in the pages of his namesake journal. The journal records Hambone's excursions and asks: how could we know more about where Hambone touches down? Might Howe's urge 'to move forward into unknown / Crumbling compulsion of syllables' ${ }^{43}$, or bell hooks's 'ancestral bodies . . surfacing in the watery passage / beyond death' ${ }^{44}$ hold some clues to Hambone's flight, or share in his compulsions? Or, in a register more in line with the violent history from which Hambone sprang, might he be found among the Haitian refugees who are the subject of Kamau Brathwaite's 62page contribution to Hambone 12 published in $1995 ?^{45}$ In bringing such figures and subjects together, Hambone makes a record of Hambone's generative movements via the cross-cultural engagements afforded by print. When Mackey describes Hambone as performing 'cross-cultural work with an emphasis on the centrifugal', the cross-cultural is also cross-medial: a point of printed articulation for a vernacular figure whose obscured yet reverberating history tracks the centrifugal and itinerant force of cross-cultural creative expression.

The effects of Mackey's cross-cultural work register in Eliot Weinberger's letter to Mackey in response to Hambone's first two issues. Around the time Hambone 2 came out, Weinberger, who was the editor of the respected Montemora literary journal, had published an essay in Poetry East lamenting the absence of writers of color in avant-garde circles. Mackey in fact cites this essay in his brief statement on editing Hambone, where he quotes Weinberger 
saying, 'On the aesthetic Left, the magazines are publishing many more women than they used to, but are not attracting young writers from the minorities, despite the presence of major avantgarde minority figures'. ${ }^{46}$ This is the background for Weinberger's November 1983 letter to Mackey:

The most disastrous effect of the post-1970 apartheid policy is that it has created separate channels of communication. The black small presses and magazines are simply not seen outside of the network of black writers. They are rarely in the literary (white) bookstores; no press or magazine ever sent Montemora review or exchange copies; etc. Rather than fostering a pluralistic society, we have a situation where the various groups are talking to themselves in isolated rooms.

This is where I see Hambone making a tremendous difference. As a black writer, you are clearly plugged into networks that I or Clayton [Eshleman] or [Robert] Bertholf are not. And you are obviously interested in some of the best writing done by white writers at the moment. Hambone—-for the first time in 20 years - is a magazine where black and white writers can read each other. For me at least, this is worth a 100 Conjunctions or Callaloos. ${ }^{47}$

Weinberger's praise for Hambone leaves some questions in the air. Who or what, for instance, instituted the "post-1970 apartheid policy" to which he refers? We do not get an answer. Still, the letter provides insight into the constitution of the small-press scene in the United States in the early 1980s and for the decade or two preceding. Whereas Callaloo published primarily black experimental writers and Conjunctions primarily white ones, Hambone drew them together. It bridged Weinberger's perceived 'apartheid' by introducing a Caribbean-influenced cross-cultural 
poetics to a U.S. American scene where its absence hinted at the 'presumably closed orders of identity and signification' that Mackey's editorial poetics has long sought to open up.

\section{On Hospitality and Hambone's Call}

Since its inception, Hambone's conceptual terrain has shifted around Mackey's understanding of the call a journal puts forth. The contributors and their poetic and political interests form the bassline for Hambone's poetic refrain. 'As in the music the journal's name refers to', we have seen Mackey comment, 'this is what one wants: that the call not go without response'. ${ }^{48}$ Mackey was careful in directing the initial call, acknowledging that he solicited all the work for Hambone 2 when he resumed publishing the journal in the early 1980s. He writes that his 'aim in composing the issue entirely of solicited work was to delineate the magazine's intended range and reach, to sketch out some of what I intended to be its defining dispositions and concerns' ${ }^{49}$ The result was a set of contributors who draw a literary map and establish a range of interests not exclusive to the United States. ${ }^{50}$ While the physical range of the journal would be limited to U.S. circulation primarily, the conceptual range Hambone calls forth is provocative for eliciting crosscultural engagements in contemporary American writing.

Despite Mackey's editorial hand guiding the project, Hambone's itinerary was not always foreseen. Many contributors to Hambone 2 continue to publish in the journal's pages, and yet in reflecting on his editorial work Mackey also appreciates the unexpected responses that Hambone 2 provoked:

That issue was a call, a summons, an invitation to those who located themselves in the terrain it mapped to submit work ... I've been especially gratified to 
receive a good deal of unsolicited work that fit, to be introduced to the work of writers I wasn't previously aware of but who, in some cases, have become regular contributors, to be taken, especially by the work of such writers as Anne-Marie Albiach, Max Aub, Julio Cortázar, Mahmoud Darweesh [sic], and Alejandra Pizarnik, submitted by translators, in directions I hadn't planned or foreseen. As in the music the journal's name refers to, this is what one wants: that the call not go without response..$^{51}$

While Mackey has editorial control of his journal, he notes that blindness also guides editorship. Mackey says as much: 'I was especially gratified . . . to be taken . . . in directions I hadn't planned or foreseen'. Hambone remains open to authors Mackey had not previously known. And it shows some humility on Mackey's part to acknowledge that much of what he had not known is due to the limitations set in place by languages, limitations overcome in part by translation. Lodged in Mackey's comment is a practical and conceptual reflection on editing and collective literary work: an editor cannot know all authors and languages and so a journal thinks more openly than any sole editor can.

Mackey's diction in the above passage also initiates a reflection on the function of hospitality in Hambone's call. Words such as 'call', 'summons', 'invitation', 'terrain', and 'gratified' all participate in an economy of hospitality, particularly as it was theorised in Jacques Derrida's late essay 'Hostipitality'. Derrida begins by pointing out the paradox of hospitality in Kant's theory of perpetual peace, ${ }^{52}$ in which Kant claims that 'Cosmopolitan Right shall be limited to Conditions of Universal Hospitality'. The paradox, which Derrida terms an aporia, is that 'universal hospitality' is in fact 'limited' because Kant conceives of it as a 'law'. This aporia — between universality and conditionality — makes hospitality a threshold within Derrida's 
late thought, and it leads him to the claim he reflects on for most of the essay: 'We do not know what hospitality is [Nous ne savons pas ce que c'est que l'hosptitalité]. Not yet'. ${ }^{53}$ Our inability to know what hospitality is has to do with the shifting nature of its terms: hospitality has its root in hote, which means both host and guest and is also related to hostis, which means enemy. The shifting of positions in a scene of hospitality disallows knowledge of pure hospitality.

Mackey's editorial poetics and Derrida's theorization of hospitality converge on the condition of 'not knowing'. Derrida works through his aporetic axiom-we do not know what hospitality is, not yet - by way of four 'acceptations'. The acceptations belong to the discourse of hospitality and denote 'the action of receiving, the welcome given, the way one receives'. ${ }^{54} \mathrm{I}$ focus here on his first acceptation, which stresses our 'not knowing' what hospitality is: 'This not-knowing is not necessarily a deficiency, an infirmity, a lack. Its apparent negativity, this grammatical negativity (the not-knowing) would not signify ignorance, but rather indicate or recall only that hospitality is not a concept which lends itself to objective knowledge' ${ }^{55}$ Such not-knowing bears on Mackey's conception of Hambone's call, for in eliciting the unforeseen it also elicits not-knowing as fundamental to literary receptivity; it suggests that the poetic, too, does not lend itself easily to objective knowledge. This is not to say that Hambone simply demonstrates that we cannot know hospitality, or that objective knowledge can be difficult to come by. Rather, Mackey portrays the emergence of the unforeseen as the 'gratifying' effect of Hambone's call. Not-knowing becomes the condition of emergence for an other American literature in the pages of Hambone. The unplanned directions Hambone takes share a common directionality: they are centrifugal because they invite the hospitable host —in this case the literary editor - outward into a literary terrain he mapped rather blindly. And he accepts this invitation gratefully, with Mackey's use of 'gratifying' in the above passage connoting both 
pleasure and gratitude. In this sense, Hambone's call creates the terrain wherein a host and his guest meet on common yet unfamiliar ground. The call functions as both an invitation and a summons outward to the other it calls.

The not-knowing immanent to Hambone's call is related to Mackey's agenda to test 'closed orders of identity and signification' by way of discrepant engagement. Put differently, the workaday practices of discrepant engagement bring about the not-knowing immanent to Hambone's call and thereby unite Mackey's editorial labour with the partially autonomous functioning of literature itself. It is not enough to say that Hambone's call functions as a mode of not-knowing, leaving the journal in one of Derrida's conceptually hospitable aporias. Instead, Mackey's literary practices establish the grounds for a common hospitality. In his remarks on the journal, Mackey affirms that individual work creates unforeseen multiplicity from particularity: 'The publication of Hambone has thus been something of a personal undertaking — or, better, a particularist undertaking - yet with a certain drive, which every magazine should have, toward ensemblist identity and definition'. ${ }^{56}$ While Mackey sees Hambone as a personal undertakingwhich he undertakes in the actual minutia of putting the journal together, evidenced in the many boxes in Mackey's archives at Emory University dedicated to his editorship of Hambone-he recognises that the result of this undertaking extends in unforeseen directions. These directions become available by way of Mackey's editorial work, and also by way of the work of other writers and translators who co-create the terrain Hambone plots. An economy of literary hospitality, multiply constituted, generates its own modicum of autonomy, figured in Mahmoud Darwish's issue-opening contribution to Hambone 3 (1983), whose speaker walks among Palestinian exiles:

we walk in the direction of a distant song we walk toward the first freedom 
and we touch the world's beauty for the first time $\ldots{ }^{57}$

This collective and itinerant autonomy is partial, flawed, beautiful, and ever-changing. It is also that which balances authorial and editorial direction with an operative and autonomous condition of blindness: the unforeseen, not-knowing generated in part by Mackey's editorial poetics is coconstituted by the intellectual work of others.

Derrida's conception of hospitality helps to clarify how intellectual labour generates the 'not-knowing' I associate here with literary autonomy. In his discussion of the first acceptation of hospitality mentioned earlier, Derrida writes that 'Hospitality, if there is such a thing, is not only an experience in the most enigmatic sense of the word, which appeals to an act and an intention beyond the thing, object, or present being, but is also an intentional experience which proceeds beyond knowledge toward the other as absolute stranger, as unknown, where I know that I know nothing of him'. ${ }^{58}$ Derrida sets the movements of hospitality in two directions here. On the one hand, hospitality is an enigmatic experience which 'appeals to' an act beyond 'the thing, object, or present being'. This is the call of hospitality, which invites the emergence of non-objective knowledge within its experiential parameters. On the other hand, hospitality is an 'intentional experience which proceeds beyond' the parameters of objective knowledge toward the 'absolute stranger'. In this second formulation, hospitality prompts outward movement, an 'intentional experience' that proceeds beyond things as they are currently thought exist. Taken together, the two halves of Derrida's claim configure hospitality as both centripetal and centrifugal. The appeal calls outward and invites the 'beyond' to it. The 'intentional experience', by comparison, moves with the call and proceeds beyond its initial knowledge. While intention compels the latter experience of hospitality, the experience proceeds beyond its instigating intention, thereby becoming an outward-moving force lodged within hospitality's appeal. Derrida never mentions labour as such in his article on hospitality—perhaps the idiom is too 
different from the one he seeks to develop. Yet his 'intentional experience' that proceeds beyond knowledge nevertheless reflects on the forms of practice that might give rise to hospitality. Understanding Derrida's intentional experience in such a way allows us to reflect on intellectual labour - and in the context of this essay, forms of literary practice — as a generative locus of hospitality.

Allow me to rephrase, then, by thinking with Mackey and Hambone: the condition of possibility for the unforeseen to emerge is intellectual labour cognisant of the not-knowing it itself creates. This is what I would call the labour of hospitality: it accepts and even invites notknowing as the return on that labour. Labour, in this sense, becomes a practice of hospitable receptivity, a method of discrepant engagement that subtly pries apart closed orders of identity and signification. It creates the conceptual terrain for meeting and receiving an unforeseen other. Hambone's ongoing call, emitted in part by Mackey's editorial labours and in part by an ongoing tradition of creative expression as a protest against divisions of labour, creates a literary terrain in which the concept of hospitality becomes imaginable if not entirely realisable. And it is not realisable because the call proceeds beyond knowledge, keeping the concept of literary hospitality in flight. Put differently, the intellectual labour of assembling Hambone sets the figural Hambone on an expedition. Mackey describes Hambone as 'cross-cultural work with an emphasis on the centrifugal ${ }^{59} \mathrm{He}$ joins work — the labours of literary practice—with the flight of literary autonomy: literature proceeds beyond the labour that begets it. Aesthetic autonomy moves with and emerges from practices of hospitality.

\section{'Destination Out': On Centrifugal Inconclusion}


In Paracritical Hinge, Mackey groups his brief essay on editing Hambone with two other short essays that weigh centrifugal and marginal forces in contemporary experimental writing. These three essays make up only ten pages of a 350-page book. Yet they offer some of Mackey's most lucid statements concerning divisions of intellectual labour as they relate to experimental writing in general, and black experimental writing in particular. 'Destination Out' (2000) shows how Mackey's centrifugal and discrepant poetics engages with such perceived divisions of labour. In Mackey's body of work, this brief essay of only three paragraphs reads more like a manifesto than any other. The poetic polemic establishes a literary pedigree going back to René Depestre's 'Hello and Goodbye to Négritude' (1980) in which Depestre questions the Négritude movement in African and Afro-Caribbean writing and calls for a cross-cultural, pan-Caribbean movement; it also echoes Alejo Carpentier's surrealist novel of expeditious flight, The Lost Steps (1953). I leave aside Mackey's engagement with those intertexts, however, to address how he conceives of 'Black centrifugal writing' as a form of discrepant engagement with avant-garde discourse, an engagement that elicits the kinds of cross-cultural poetics he pursues. Mackey's centrifugal poetics seeks to recuperate experimental forms of black intellectual and creative labour — and to emphasize their capacity to work cross-culturally - in such a way that the recuperation need not be bound to narratives of cultural or economic incorporation some theorists have seen as integral to avant-garde discourse. ${ }^{60}$

Mackey begins 'Destination Out' by joining creative work with centrifugal force. 'Centrifugal work', he writes, 'begins with good-bye, wants to bid all givens good-bye. It begins with what words will not do, paint will not do, whatever medium we find ourselves working in will not do. Amenities and consolation accrue to a horizon it wants to get beyond, abandoning amenities and consolation or seeking new ones. It will, of course, suffer marginalization, 
temporary in some cases, unremitting in most' ${ }^{61}$ Mackey begins assertively, declaring that 'centrifugal work begins with good-bye'. He immediately qualifies his claim, however, saying it 'wants' to bid good-bye to all givens. This is an important transition, for Mackey's 'want' here is not a sourceless desire so much as a desire that arises from working within the context of 'all givens'. Mackey solidifies this point in the following sentence, noting that centrifugal work begins with 'whatever medium we find ourselves working in will not do'. For Mackey, media are limiting forms that gesture beyond their own givenness to what they cannot do and what we, relatedly, cannot know. Mackey then proposes that the apprehension of medial limitation introduces centrifugal force into literary work. This apprehension comes about through 'work', including through literary practices such as editing and writing.

Stating that centrifugal work 'begins with good-bye', Mackey makes work into the condition of possibility for proceeding beyond what is given. He insists on this point for a specific reason: the work of black experimentalism is too often conflated with the task of constructing a stable black identity. Mackey understands this sleight of hand — from work to identity — to be the result of specific divisions of intellectual labour and categorizations of creative expression, particularly those resulting from academic discourse. In the second paragraph of his tract, Mackey argues that

Black centrifugal writing has been and continues to be multiply marginalized. Why would it be otherwise? At a time when academic and critical discourse battens on identity obsession (even as it 'problematizes' identity), black centrifugal writing reorients identity in ways that defy prevailing divisions of labor. In the face of a widespread fetishization of collectivity, it dislocates 
collectivity, flies from collectivity, wants to make flight a condition of collectivity. ${ }^{62}$

Mackey sets myriad concepts in motion here without always tracking their many trajectories in full. If we follow through on his centrifugal metaphor, for instance, would it not make sense that centrifugal writing —in its movement outward — ends up on the margins? Yet it is precisely such 'center / margin' dichotomies that Mackey attempts to displace by situating the centrifugal at the heart of collectivity. Centrifugal work 'wants to make flight a condition of collectivity' so that what Mackey calls 'prevailing divisions of labor' in academic discourse cannot so easily ascribe the work of black creative expression to a stable black identity. Mackey's work on Hambone launches a protest against racialised divisions of intellectual labour and creative identity while simultaneously making creative labour-Mackey's editorial poetics — the point of commencement for centrifugal displacement. 'Destination Out' outlines a methodology attentive to the myriad forms of intellectual and creative labour while resisting centripetal forces- the drive toward categorical identification, the imposition of truth on the Other-that would seek to bind labour's creative and disruptive potential.

Mackey, we know, does not work alone. His particularlist undertaking gives way to ensemblist identity and form. The work Hambone's call undertakes is twinned, repeatedly, in the literary corpus the call helps to create. Take, for instance, Al Young's contribution to Hambone 2. In a poem titled 'What is the Blues?', a speaker uncannily similar to Hambone starts out,

Far away, I suppose you could say, Is where I'm always coming back from. In any event, it's where I want to be -naked, undressable, inaccessible, at the tip edge of the vanishing point. ${ }^{63}$

Like Hambone, this figure's address wavers between return and departure, making 'the tip edge of the vanishing point' a commentary not only on his imagined destination but also on the poem 
itself as an unsettled node of transition. Mahmoud Darwish, whose work was unknown to Mackey before the poet and translator Stephen Kessler submitted a selection to him after the publication of Hambone 2, also reflects on itinerancy and poetic departure. His Palestinian refugees, we have seen, 'walk in the direction of a distant song ... and ... touch the world's beauty for the first time'. ${ }^{64}$ The provocative overlap between Young's blues and Darwish's exilic wandering hints at the cross-cultural connections taking shape between Hambone's covers and across its issues. As if responding to the desire to be 'at the tip edge of the vanishing point', bell hooks's contribution to Hambone 3 offers a more grounded consideration of poetic expression. She writes:
i shall sing a praise song
a song my mother taught me the earth
it is round
there is no edge there is no way to fall off ${ }^{65}$

The figural Hambone and Young's speaker already know this: Hambone continually returns from his trip; and 'far away' is where Young's speaker 'is always coming back from'. Yet having 'no way to fall off' does not undercut the centrifugal work of Hambone's call and the itinerancy it charts. It rather rearticulates Mackey's desire to show how flight and collectivity converge, and how this provisional convergence gives one a place to depart from again and again.

Hambone offers such a point of departure. It recuperates a notion of experimental expression that maintains its disruptive potential by insisting that creative labour makes rickety fits not only between the word and the world, as Mackey notes, but also between work and the world of letters. Hambone is a critical figure — and Hambone a vital journal—for considering creative work historically and at present. Hambone emerged as a figure of intellectual freedom 
from people who suffered the most violent division of labour. Those unnamed and unknown who created Hambone, and who made him prominent in a vernacular tradition, had their physical labour and freedom stripped from them. Their creative work, however, remained in flight from, yet in engagement with, the impositions of Western modernity. We glimpse this ongoing flight in Hambone's call, which calls so that we may answer. 
${ }^{1}$ Nathaniel Mackey, 'Editing Hambone', in Paracritical Hinge: Essays, Talks, Notes, Interviews (Madison: University of Wisconsin Press, 2005), p. 244.

${ }^{2}$ This first issue is difficult to acquire, though one can now see its table of contents on Hambone's webpage, www.hambone.org/back-issues.

${ }^{3}$ Mackey, 'Editing Hambone', p. 244.

${ }^{4}$ Nathaniel Mackey, 'Introduction: And All the Birds Sing Bass', in Discrepant Engagement: Dissonance, Cross-Culturality, and Experimental Writing (Tuscaloosa: The University of Alabama Press, 1993), p. 19.

${ }^{5}$ Mackey, ‘Editing Hambone’, p. 244.

${ }^{6}$ Some writers from Hambone 1 have proven difficult to find, as they did not become renowned figures and perhaps did not continue writing for publication.

${ }^{7}$ Susan Howe, 'mute memory vagrant memory', in Hambone 2, edited by Nathaniel Mackey (Santa Cruz, CA: Hambone, 1982), p. 23.

${ }^{8}$ Susan Howe, 'right or ruth', in Hambone 2, edited by Nathaniel Mackey (Santa Cruz, CA: Hambone, 1982), p. 28.

${ }^{9}$ For a reading of Howe's allusions to Spenser and the English colonisation of Ireland, see Will Montgomery, 'Susan Howe's Renaissance Period: Metamorphosis and Representation in Pythagorean Silence and Defenestration of Prague', Journal of American Studies 40 (2006), pp. 615-633.

${ }^{10}$ At greater length Metcalf writes, 'HAMBONE is a delight! Really, one of the freshest reading experiences to come in a long time. Clearly, you set out to include as wide a range as possibleI'm sure you've been told this many times - but what is remarkable is not only the range, but the quality of nearly every submission. It's a genuine all-star show - as though we all knew, somehow, we had to be on our toes. How did that happen? My personal favorites: [John] Taggart, [Susan] Howe, [Kamau] Brathwaite, and [Ishmael] Read [sic]. (How could anybody include Taggart and Read [sic] in the same magazine? Well, Nate Mackey could, that's how / who.) Cheers! [signed] Paul [Metcalf]'. Paul Metcalf, 'Letter to Nathaniel Mackey', 12 November 1982, Nathaniel Mackey Papers, MSS 1297, Box 28. Folder: Hambone Correspondence, 1982. Emory University. The contributor Judy Platz shows her intuitive understanding of Hambone, writing in her thank you letter that 'HAMBONE is a real, concrete, energy force now ... You are, you know, MAKING your own "Crossroads Choir"', a reference to the fictional band in Mackey's early letters of From a Broken Bottle. Judy Platz, 'Letter to 
Nathaniel Mackey', 26 November 1982, Nathaniel Mackey Papers, MSS 1297, Box 28. Folder: Hambone Correspondence, 1982. Emory University.

${ }^{11}$ John Taggart, 'Very Slow', in Hambone 2, edited by Nathaniel Mackey (Santa Cruz, CA: Hambone, 1982), p. 6.

${ }^{12}$ Ishmael Reed, 'Ishmael Reed Replies to Amiri Baraka', in Hambone 2, edited by Nathaniel Mackey (Santa Cruz, CA: Hambone, 1982), p. 123.

${ }^{13}$ Mackey, 'Editing Hambone', p. 246.

${ }^{14}$ Ibid.

${ }^{15}$ Loren Glass, 'Introduction: From Avant-Garde to Counterculture', in Counterculture Colophon: Grove Press, the Evergreen Review, and the Incorporation of the Avant-Garde (Stanford, CA: Stanford University Press, 2013), pp. 1-32.

${ }^{16}$ Peter Bürger, Theory of the Avant-Garde, trans. Michael Shaw (Minneapolis: University of Minnesota Press, 1984), pp. 57-58.

${ }^{17}$ See Paul Mann, The Theory-Death of the Avant-Garde (Bloomington: Indiana University Press, 1991).

${ }^{18}$ Mann, Theory-Death, p. 4.

${ }^{19}$ Mackey, 'Editing Hambone’, p. 246.

${ }^{20}$ Mackey, 'And All the Birds Sing Bass', qtd. in 'Editing Hambone', p. 247.

${ }^{21}$ The persistence of this call in Mackey's editorial poetics anticipates the theories developed in Stefano Harney and Fred Moten's The Undercommons: Fugitive Planning and Black Study. Jack Halberstam outlines the most salient overlap in their introduction: 'Moten and Harney want to gesture to another place, a wild place that ... continuously produces its own unregulated wildness. The zone we enter through Moten and Harney is ongoing and exists in the present and, as Harney puts it, "some kind of demand was already being enacted, fulfilled in the call itself". While describing the London Riots of 2011, Harney suggests that the riots and insurrections do not separate out "the request, the demand and the call"-rather, they enact the one in the other: "I think the call, in the way I would understand it, the call, as in the call and response, the response is already there before the call goes out. You're already in something". You are already in it. For Moten too, you are always already in the thing that you call for and that calls you. What's more, the call is always a call to dis-order and this disorder or wildness shows up in many places: in jazz, in improvisation, in noise .... Listening to cacophony and noise tells us that there is a wild beyond to the structures we inhabit and that inhabit us'. This essay proposes that Hambone's call also gestures to this wild, dis-organizing beyond. It is itself a call to disorder. Jack Halberstam, 'The Wild Beyond: With and For the Undercommons', in Stefano Harney and Fred Moten The Undercommons: Fugitive Planning and Black Study (New York: Minor Compositions, 2013), p. 7. 
${ }^{22}$ Mellonee V. Burnim, Portia K. Maultsby, and Susan Oehler, 'Intellectual History', in Mellonee V. Burnim and Portia K. Maultsby (eds.) African American Music: An Introduction (New York: Routledge, 2006), p. 8.

23 Ibid.

${ }^{24}$ I follow the editors of African American Music in using Black as an umbrella term for people of different ethnicities-African, African American, Afro-Caribbean - in the Americas.

${ }^{25}$ Mackey, 'Editing Hambone', p. 248.

${ }^{26}$ Lawrence W. Levine, 'African American Music as Resistance, Antebellum Period', in Mellonee V. Burnim and Portia K. Maultsby (eds.) African American Music: An Introduction (New York: Routledge, 2006), p. 589.

27 Ibid., p. 590.

${ }^{28}$ Burnim and Maultsby, Introduction, p. 25.

29 'Stono Rebellion', in Leslie M. Alexander and Walter C. Rucker (eds.) Encyclopedia of African American History, Vol. 2, (ABC-CLIO, 2010).

${ }^{30}$ Mark Morgan, dir., The Human Hambone (First Run/Icarus Films, 2005).

${ }^{31}$ Nathaniel Mackey, From a Broken Bottle Traces of Perfume Still Emanate, Vols. 1-3 (New York: New Directions, 2010), p. 124.

${ }^{32}$ In addition to the twenty-one book-length volumes of Hambone, Mackey has also co-edited Moment's Notice: Jazz in Poetry and Prose with Art Lange and was co-editor with Marjorie Perloff and Carolyn Kizer of the Library of America's American Poetry volume covering the twentieth century. The emphasis I place on the name Mackey gave his journal falls in line with Mackey's other literary work, particularly From a Broken Bottle, in which character and band names morph and develop throughout the series. For an excellent reading of 'puncepts' in Mackey's work, which also considers his naming practices, see Adelaide Morris, 'Angles of Incidence / Angels of Dust: Operatic Tilt in the Poetics of H.D. and Nathaniel Mackey', Callaloo, 23 (2000): 749-64.

${ }^{33}$ Mackey, 'Editing Hambone', p. 246.

${ }^{34}$ Ibid., p. 245.

${ }^{35}$ Mackey, 'Introduction: And All the Birds Sing Bass', p. 5

${ }^{36}$ Quoted in Mackey, 'And All the Birds Sing Bass', p. 5. Some of the quotations I use follow the quotations that Mackey himself uses. Even among poets and poet-critics, Mackey is particularly shrewd in his critical reflections on his own work, particularly in the introductions to 
Discrepant Engagement and Paracritical Hinge. With this in mind, I try to think with Mackey while offering what I hope to be readings of his own critical assertions that offer further insight into Mackey's poetics.

37 'expedite, v.' 2016. OED Online (Oxford: Oxford University Press).

http://www.oed.com.ezaccess.libraries.psu.edu/view/Entry/66486? isAdvanced=false\&result=2\& rskey=uZAFyd\&

${ }^{38}$ For an excellent introduction to Harris's own testing of an 'expedition into wholeness', see his novel Palace of the Peacock (1960), which narrates a surreal and mystical journey into inland Guyana. The narrative depends heavily on various images rotating through the 'partial' vision of the narrator, who has one 'dead seeing material eye' and one 'living closed spiritual eye' (Harris $1985,20)$. Through this split vision, both historical and visionary, Harris seeks to narrate a partial history of the colonisation of Guyana and its effects.

${ }^{39}$ Harris's The Womb of Space: The Cross-Cultural Imagination (1983) has also been a touchstone for Mackey with regard to cross-cultural poetics.

${ }^{40}$ Quoted in Mackey, 'And All the Birds Sing Bass', pp. 5-6.

${ }^{41}$ Édouard Glissant, Caribbean Discourse: Selected Essays, trans. J. Michael Dash (Charlottesville: University Press of Virginia, 1989), p. 147.

${ }^{42}$ Ibid., 149.

${ }^{43}$ Howe, 'Twenty lines of', in Hambone 2, edited by Nathaniel Mackey (Santa Cruz, CA: Hambone, 1982), p. 31.

${ }^{44}$ bell hooks, 'in the manner of the egyptians', in Hambone 2, edited by Nathaniel Mackey (Santa Cruz, CA: Hambone, 1982), p. 5.

${ }^{45}$ Kamau Brathwaite, 'Dream Haiti', in Hambone 12, edited by Nathaniel Mackey (Santa Cruz, CA: Hambone, 1995), pp. 123-185.

${ }^{46}$ Eliot Weinberger, qtd. in Nathaniel Mackey, 'Editing Hambone’', p. 247.

${ }^{47}$ Eliot Weinberger. 'Letter to Nathaniel Mackey'. 1 Nov. 1983. TS. Nathaniel Mackey Papers. Emory University.

${ }^{48}$ Mackey, 'Editing Hambone’' p. 248.

${ }^{49}$ Ibid. 


\begin{abstract}
${ }^{50}$ The conceptual range Mackey sought to cover with Hambone 2 is hinted at in one of his letters soliciting work for the issue. In 1980, Mackey wrote to the poet Robert Kelly, asking him to contribute some of his writing. He writes, 'I'm especially interested in some poems you read in Boulder back in the fall of 1977 and which I heard on the public library's videotape of the reading. I recall you introducing them by remarking on your sense of rapport between Black and Irish investments in eloquence, which you carried back to Egypt as a common source ... You say at one point, "And we were black, two spurs of Egypt, Celts and Bantus." . . Can't offer much of an overture as far as the thrust I want to give the mag is concerned. "Crossings" is a word which comes to mind, as does the much more widely worked expression "New World poetics"- but I wouldn't push either one of them beyond what particular work gives substance to'. Nathaniel Mackey, 'Letter to Robert Kelly', 27 February 1980, Kelly (Robert) Collection, B78F3. The Poetry Collection. University at Buffalo.
\end{abstract}

${ }^{51}$ Mackey, 'Editing Hambone', p. 248.

52 Jacques Derrida, 'Hostipitality', trans. Barry Stocker with Forbes Morlock, Angelaki: A Journal of the Theoretical Humanities 5 (2000), p. 3.

53 Ibid., p. 6.

${ }^{54}$ Ibid., p. 7.

55 Ibid.

${ }^{56}$ Mackey, 'Editing Hambone’, p. 246.

${ }^{57}$ Mahmoud Darweesh [sic], 'From Beirut', in Hambone 3, edited by Nathaniel Mackey (Santa Cruz, CA: Hambone, 1983), p. 5.

${ }^{58}$ Derrida, 'Hostipitality', p. 8.

${ }^{59}$ Mackey, 'Editing Hambone’, p. 245.

${ }^{60}$ I am thinking here of Mann's Theory-Death of the Avant-Garde and Glass's CountercultureColophon, both referenced above.

${ }^{61}$ Nathaniel Mackey, 'Destination Out', in Paracritical Hinge: Essays, Talks, Notes, Interviews (Madison: University of Wisconsin Press, 2005), p. 239.

62 Ibid.

${ }^{63}$ Al Young, 'What is the Blues?', in Hambone 2 (Santa Cruz, CA: Hambone, 1982), p. 57.

${ }^{64}$ Darweesh [sic], 'From Beirut', p. 5.

${ }^{65}$ bell hooks, 'the body inside the soul', in Hambone 3 (Santa Cruz, CA: Hambone, 1983), p. 88. 
